Cornell Law Library Scholarship@Cornell Law: A Digital Repository

Cornell Law Faculty Publications

$1-29-2008$

\title{
The State Attorney General and Preemption
}

Trevor W. Morrison

Cornell Law School, twm25@cornell.edu

Follow this and additional works at: http://scholarship.law.cornell.edu/lsrp_papers

Part of the Administrative Law Commons, and the Legislation Commons

\section{Recommended Citation}

Morrison, Trevor W., "The State Attorney General and Preemption" (2008). Cornell Law Faculty Publications. Paper 91.

http://scholarship.law.cornell.edu/lsrp_papers/91

This Article is brought to you for free and open access by Scholarship@Cornell Law: A Digital Repository. It has been accepted for inclusion in Cornell Law Faculty Publications by an authorized administrator of Scholarship@Cornell Law: A Digital Repository. For more information, please contact jmp8@cornell.edu. 


\title{
CORNELL LAW SCHOOL
}

\section{Legal StUdies ReseARCH PAPER SERIES}

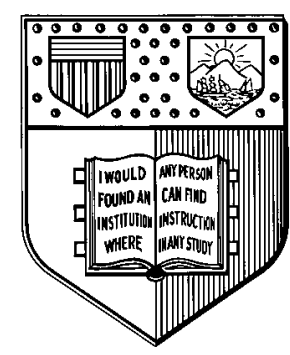

\section{The State Attorney General and Preemption}

\author{
Trevor W. Morrison
}

\author{
Cornell Law School \\ Myron Taylor Hall \\ Ithaca, NY 14853-4901
}

Cornell Law School research paper No. 08-001

This paper can be downloaded without charge from:

The Social Science Research Network Electronic Paper Collection:

http://ssrn.com/abstract $=1088136$ 


\section{The State Attorney General ANd Preemption}

\section{Trevor W. Morrison*}

According to the National Association of Attorneys General ("NAAG"), "the rise of preemption of state laws and regulations by federal administrative agencies, rather than directly by Congress" is "[p]erhaps the most significant development in federal preemption in the last several decades." 1 This kind of preemption is typically claimed in an agency ruling or regulation declaring certain state laws or activities preempted, even though the underlying statute says nothing about preemption in those areas. That NAAG would view "agency preemption" as particularly worrisome is hardly surprising: the main casualties are often state attorneys general, whose broad investigative and enforcement powers under state consumer protection, health, environmental, and other state laws are displaced by the agency's action.

This chapter examines the implications of agency preemption for state attorneys general, and vice versa. Its principal intended audience is not so much the courts as Congress and the federal agencies themselves; its prescriptions are less about judicial doctrine (though there are implications along those lines) than about choices the legislature and agencies could make to better accommodate the important functions of state attorneys general. As to Congress, I suggest that it should directly address whether any or all of the work of state attorneys general should be preempted by any particular enactment it passes, and should include a provision making clear the extent of its intent to preempt. As to agencies, I suggest that, in the absence of clear statutory language addressing the question, agencies should be reluctant to promulgate regulations preempting the investigatory or enforcement authority of state attorneys general. Unlike the Supreme Court's current "presumption against preemption," the approach I advocate does not focus on the particular subject matter of the state or federal law in question. Instead, it focuses on the identity of the actor enforcing the state law. Given the electoral accountability of most state attorneys general and their longstanding mandates to enforce state laws in pursuit of the public interest, I suggest that unelected federal agencies should be particularly reluctant, absent a clear statutory mandate, to displace the work of state attorneys general. Instead, I suggest that federal law should preempt the work of state attorneys general only by express statutory language.

To get to those prescriptions, Part I first provides a brief overview of the federalismrelated values that bear most directly on a consideration of state attorneys general. Part II then introduces the state attorney general, emphasizing that most such officers are directly elected and that they typically wield broad authority not only to initiate court proceedings in the public interest but also to monitor compliance with both state and federal law. As Part III describes, however, the problem for state attorneys general is that the courts' current preemption doctrine takes no special account of state attorneys general. Thus, courts have recently upheld the "agency preemption” of state attorneys

\footnotetext{
* Associate Professor, Cornell Law School.

${ }^{1}$ National Association of Attorneys General Preemption Working Group, The Law of Preemption (Washington, DC, 2004), 19.
} 
general in certain areas. In addition, judicial preemption doctrine is sufficiently malleable and unpredictable that it can be difficult to know when, and why, the actions of state attorneys general will or will not be preempted. Although it is certainly possible that the courts themselves could improve their doctrine in this area, a more direct approach would be for Congress and federal agencies to take account of the state attorney general themselves. Part IV proposes that they do just that. Finally, Part V identifies and responds to a potential objection.

\section{Federalism and Democratic Accountability}

In Chapter One of this volume, Professors Mendelson and Verchick explore the theoretical underpinnings of, and connections between, preemption and federalism. ${ }^{2}$ Building on that discussion, I want to highlight here four points that will help situate state attorneys general within the framework of federalism.

First, although there are a variety of accounts of federalism, its core characteristics include the following: (1) the powers of the federal government are limited but supreme within their compass, (2) the residual powers of the states are broad and plenary, and (3) the areas in which the Constitution grants the federal government exclusive authority are few, while the areas subject to concurrent and overlapping federal and state regulation are many. This last point is critical. The Constitution tends not to create exclusive federal and state zones, but to tolerate overlapping federal and state regulation. ${ }^{3}$ Ordinarily, then, the fact that the federal government is competent to act in a particular area does not by itself preclude state involvement in that area. To be sure, there are exceptions to this principle. Some areas, like foreign affairs, the Constitution commits to exclusive federal control. ${ }^{4}$ But in the main, the Constitution creates overlapping and even interacting zones of federal and state governance.

\footnotetext{
${ }^{2}$ See supra pp. _- -
}

${ }^{3}$ United States v. Locke, 529 U.S. 89, 109 (2000) ("It is fundamental in our federal structure that States have vast residual powers. Those powers, unless constrained or displaced by the existence of federal authority or by proper federal enactments, are often exercised in concurrence with those of the National Government.”); Caleb Nelson, “Preemption,” Virginia Law Review 86, no. 2 (2000): 225 (“The powers of the federal government and the powers of the state overlap enormously. Although the Constitution makes a few of the federal government's powers exclusive, the states retain concurrent authority over most of the areas in which the federal government can act.”).

4 American Ins. Ass’n v. Garamendi, 539 U.S. 396, 413 (2003) (discussing “the Constitution’s allocation of the foreign relations power to the National Government”). Immigration is arguably another such area, although recent scholarship suggests that state and local governments may legitimately have more of a role in this area than is commonly thought. See Clare Huntington, "The Constitutional Dimension of Immigration Federalism,” Vanderbilt Law Review (forthcoming 2008); Cristina Rodriguez, “The Significance of the Local in Immigration Regulation," Michigan Law Review (forthcoming 2008); Peter Schuck, “Taking Immigration Federalism Seriously," University of Chicago Law Review (forthcoming 2008). In part, these pieces build on earlier work by Peter Spiro. See, e.g., Peter J. Spiro, "The States and Immigration in an Era of Demi-Sovereignties," Virginia Journal of International Law 35, no. 1 (1994): 121. 
Second, federalism is often presented in instrumental terms. ${ }^{5}$ That is, federalism is depicted not as an end in itself, but as a means of achieving other important goals. Many of the modern Supreme Court's statements about federalism take this form. In Gregory $v$. Ashcroft, for example, Justice O'Connor's majority opinion identified a number of ends to which the Court considers federalism a useful means:

This federalist structure of joint sovereigns preserves to the people numerous advantages. It assures a decentralized government that will be more sensitive to the diverse needs of a heterogeneous society; it increases opportunity for citizen involvement in democratic processes; it allows for more innovation and experimentation in government; and it makes government more responsive by putting the States in competition for a mobile citizenry. ${ }^{6}$

Third, as the passage from Gregory reveals, democratic accountability is often identified as one of federalism's key payoffs. ${ }^{7}$ The idea here is that "[t]he greater accessibility and smaller scale of local [and state] government allows individuals to participate actively in governmental decision-making. This participation, in turn, provides myriad benefits, [including that it] fosters accountability among elected representatives." 8 This is really a point about decentralization: by leaving the states with substantial room to govern, federalism brings the citizens of each state into closer proximity with their government than would be the case in a purely national system. That closer proximity puts at least some citizens in a better position to monitor and influence government, which in turn makes government more accountable to its constituents. Although this theoretical idea will not always be perfectly realized in practice, the point here is that our federalist system is structured to pursue it. ${ }^{9}$

Fourth and finally, because federalism's default position is one of overlapping federal and state governance, the federal government's decision to regulate in a particular area does not necessarily entail giving up the benefits associated with decentralized state power. Congress may decide that a particular issue within its jurisdiction demands uniform national treatment, in which case it may decide to displace state authority. But its decision to act in that area need not entail displacing the states. The exercise of national power does not necessarily come at the price of decentralized democratic accountability.

${ }^{5}$ Michael C. Dorf, “Instrumental and Non-Instrumental Federalism,” Rutgers Law Journal 28, no. 4 (1997): 825.

${ }^{6}$ Gregory v. Ashcroft, 501 U.S. 452, 458 (1991).

${ }^{7}$ Dorf, 828.

${ }^{8}$ Deborah Jones Merritt, "The Guarantee Clause and State Autonomy: Federalism for a Third Century,” Columbia Law Review 88, no. 1 (1988): 1, 7.

${ }^{9}$ As Roderick Hills puts it, this decentralizing structure is "the American version of 'subsidiarity,' the principle that power ought to be decentralized to the lowest practicable tier of social organization, public or private.” Roderick M. Hills, Jr., "Is Federalism Good for Localism? The Localist Case for Federal Regimes,” Journal of Law and Politics 21 (Spring-Summer 2005): 190. 


\section{The State Attorney General}

Having reprised the features of federalism that are most pertinent here, I now turn to the state attorney general. There are two key points here: (1) the vast majority of state attorneys general are democratically elected, and (2) most are invested with robust investigative and enforcement powers under a broad range of state (and sometimes federal) laws.

Democratic Accountability. Unlike the federal government, the vast majority of state governments feature executive branches that are formally divided, with executive power apportioned among different executive actors not subject to direct gubernatorial control. ${ }^{10}$ In nearly every state, one of those executive actors is the state attorney general: the attorney general is popularly elected in forty-three states. ${ }^{11}$ Thus, the overwhelming majority of state attorneys general are directly accountable, through the electoral process, to the citizens of their respective states.

This feature of most state attorneys general resonates strongly with federalism's concern for democratic accountability. As noted in the previous section, part of the virtue of decentralized government power is that it increases the responsiveness of government to localized priorities. State attorneys general are in a position to deliver that responsiveness or pay the penalty on Election Day. Of course, any given state attorney general may or may not do a good job of pursuing the voting public's policy priorities. But as a matter of institutional design, state-by-state election of state attorneys general makes them well situated to deliver at least some of federalism's benefits of decentralization.

Powers. The powers and duties of the state attorney general have "dramatically expanded" over time, and they also vary somewhat from state to state. ${ }^{12}$ Generally speaking, though, most attorneys general have long had the authority and duty to enforce the laws of the state in the public interest. ${ }^{13}$ "The state exists to "promote the health,

${ }^{10}$ William P. Marshall, "Break Up the Presidency? Governors, State Attorneys General, and Lessons from the Divided Executive,” Yale Law Journal 115, no. 9 (2006): 2446; Patrick C. McGinley, "Separation of Powers, State Constitutions \& the Attorney General: Who Represents the State?" West Virginia Law Review 99, no. 4 (1997): 721.

11 National Association of Attorneys General, State Attorneys General: Powers and Responsibilities (Lynn M. Ross ed., 1990) (hereinafter “Powers \& Responsibilities”): 15. In five of the remaining seven states (Alaska, Hawaii, New Hampshire, New Jersey, and Wyoming), the attorney general is appointed by the governor, ibid., though in three of those (Hawaii, New Hampshire, and New Jersey), the governor may not remove the attorney general at will. Marshall, 2448 n.3. The attorney general is selected by secret ballot of the state legislature in Maine, and by the supreme court in Tennessee. Powers \& Responsibilities, 15. For the balance of this chapter, my references to the state attorney general assume that the office is subject to direct democratic election. In the small number of states where that is not the case, the prescriptions of this chapter may apply with less force.

12 Powers \& Responsibilities, 11.

13 Ibid., 13; Jason Lynch, Note, "Federalism, Separation of Powers, and the Role of State Attorneys General in Multistate Litigation,” Columbia Law Review 101, no. 8 (2001): 1998. 
safety ... and welfare of the people,", ${ }^{14}$ and the state attorney general plays a central role in the promotion of those ends. Typically, the state attorney general is given "wide discretion in making the determination as to the public interest," and is further empowered to "exercise all such authority as the public interest requires." 15 Thus, although the precise subject matter of the laws has changed (and multiplied) over time, the state attorney general has long had the power and responsibility to assess the public interest and to enforce state law in accordance with that assessment.

Two specific dimensions of the state attorney general's powers bear highlighting here. The first is the power to investigate regulated entities' level of compliance with relevant state-and, in some cases, federal-law. Perhaps the most important form of investigative authority in this context is known as visitorial power. In many states, the attorney general is authorized to engage in "[v]isitation," which "is the act of a superior or superintending officer, who visits a corporation to examine into its manner of conducting business."16 Typically, “[v]isitors of corporations have power to keep them within the legitimate sphere of their operations, and to correct all abuses of authority, and to nullify all irregular proceedings." 17 State attorneys general are commonly granted this power to review the conduct of corporations and other entities doing business in the state. In New York, for example, the attorney general is empowered to investigate instances of "persistent fraud or illegality in the carrying on, conducting or transaction of business" in the state, and to "issue subpoenas . . . [,] take proof and make a determination of the relevant facts" in connection with such investigations. ${ }^{18}$

In addition, some states authorize the attorney general to enlist the subject-specific visitorial authority of other executive branch officials. Michigan, for example, provides that its attorney general may initiate a proceeding with the commissioner of insurance and financial services to determine whether an entity covered by state banking or related laws is complying with them. ${ }^{19}$ The commissioner, in turn, can investigate the complaint, refer the matter to the appropriate federal regulatory authority if it targets a state-

14 Richard P. Ieyoub \& Theodore Eisenberg, "State Attorney General Actions, the Tobacco Litigation, and the Doctrine of Parens Patriae,” Tulane Law Review 74, Nos. 5-6 (2000): 1863.

${ }^{15}$ Florida ex rel Shevin v. Exxon Corp., 526 F.2d 266, 268-69 (5th Cir. 1976).

${ }^{16}$ Guthrie v. Harkness, 199 U.S. 148, 158 (1905).

17 Ibid., 157-58.

${ }^{18}$ McKinney’s Exec. Law § 63(12). As discussed later in this chapter, a divided panel of the U.S. Court of Appeals for the Second Circuit recently concluded that federal banking laws preempt this provision as applied to national banks, even when the investigation is focused on a bank's compliance with state laws that are themselves not preempted by federal law. See Clearing House Ass'n v. Cuomo, _ F. 3d _, 2007 WL 4233358 (2d Cir. Dec. 4, 2007). That decision exemplifies the problem to which this chapter is addressed.

${ }^{19}$ Mich. Comp. Laws Ann. § 445.1663(1). The Supreme Court has concluded that this and related provisions of Michigan law are preempted by the National Bank Act. See Watters v. Wachovia Bank, N.A., 127 S. Ct. 1559 (2007). That decision is also reflective of the problem to which this chapter is addressed. 
chartered subsidiary of a national bank, and take further action if the matter is not “adequately pursued" by the federal agency. ${ }^{20}$

In sum, state attorneys general exercising their visitorial and related investigative powers are in a position to ascertain whether regulated entities within their jurisdictions are complying with relevant state and federal laws, to respond to consumer and other public complaints, and to root out unlawful conduct that might otherwise go undetected. The mere fact that a regulated entity is subject to the attorney general's visitorial power undoubtedly creates a powerful incentive to comply with the law. Where that fails, the visitorial power provides a means of generating the information needed to decide whether, when, and how to enforce the law. As discussed below, some of that enforcement may be undertaken by the attorney general him or herself. But as the Michigan example shows, state investigations can also yield information that is turned over to the responsible federal agency for possible enforcement at that level. State investigation, in other words, can aid federal enforcement, and perhaps even spur federal agencies into action and out of the stasis to which they sometimes fall prey. ${ }^{21}$

Of course, enforcement can also happen at the state level, the principal responsibility for which typically resides with the state attorney general. Whether under state statutory or common law, attorneys general commonly possess broad authority to sue in the public interest. As to the former, states like California have statutes empowering the attorney general to prosecute suits for injunctive relief and civil penalties against "[a]ny person who engages, has engaged, or proposes to engage" in "any unlawful, unfair or fraudulent business act or practice [or] unfair, deceptive, untrue or misleading advertising." 22 As to the latter, states like Louisiana recognize the attorney general's power to act in a parens patriae capacity by initiating nuisance, fraud, and other actions to protect the public. ${ }^{23}$ In these and other respects, the state attorney general's investigative authority is complemented by broad power to enforce state law in the public interest.

The picture that emerges here is of the state attorney general as a democratically accountable officer charged with safeguarding the public and, to that end, invested with broad-ranging authority to monitor compliance with state (and sometimes federal) laws and to initiate lawsuits or other enforcement actions when necessary. This combination of accountability and authority makes the attorney general a particularly important state institution. Although there certainly are occasions in which federal law needs to displace this institution in order to advance some overarching national regulatory goal, such displacement carries substantial costs. Given those costs, it is sensible to pause before construing any particular federal law to preempt the work of the state attorney general.

\footnotetext{
${ }^{20}$ Ibid., § 445.1663(2).

${ }^{21}$ For more on the phenomenon of federal regulatory failure, see Chapters Three and Eleven of this volume by Professors Vladeck and McGarity, respectively.

${ }^{22}$ Cal. Bus. \& Prof. Code $\S \S 17200-17205$. These same provisions of California law also allow private individuals to sue, provided they have "suffered injury in fact and ha[ve] lost money or property as a result of" the complained of activity. Ibid. $\S 17204$. Actions by the attorney general need not establish that anyone has suffered such harm.

${ }^{23}$ See generally Ieyoub \& Eisenberg.
} 


\section{State Attorneys General under Current Preemption Doctrine}

Although there are both democratic and basic law enforcement reasons to be reluctant about preempting state attorneys general, a number of recent cases have done so quite readily.

Consider, for example, OCC v. Spitzer. ${ }^{24}$ The case involved a regulation promulgated by the federal Office of the Comptroller of the Currency ("the OCC") construing the National Bank Act as granting the OCC "exclusive visitorial authority with respect to the content and conduct of activities authorized for national banks under Federal law."25 Under that construction, the OCC deems state attorneys general to be prohibited from enforcing against national banks not only state laws targeting banking in particular, but also state laws of general application forbidding such things as racial discrimination. The OCC does not deny the applicability of state anti-discrimination laws to national banks' lending and other practices. Instead, it takes the position that the OCC has exclusive authority to investigate national banks and to prosecute enforcement actions to compel their compliance with not only federal laws, but state laws as well. The National Bank Act itself contains no such provision; the OCC's regulation is thus an example of agency preemption. The district court in OCC $v$. Spitzer agreed with the agency, broadly concluding that the OCC has "exclusive authority to investigate national banks and prosecute enforcement actions to compel their compliance with state and federal laws regulating the conduct of federally authorized banking activities., ${ }^{26}$ A divided panel of the U.S. Court of Appeals for the Second Circuit recently affirmed that decision. ${ }^{27}$

OCC $v$. Spitzer may or may not be rightly decided under current preemption doctrine; there are plausible claims on both sides of the case. But to the extent the doctrine at least arguably permits results such as this, it makes preempting the work of state attorneys general quite easy. To see how this is so, it is helpful to review the main features of preemption doctrine as it currently exists. ${ }^{28}$

Preemption doctrine is designed to implement the Constitution's instruction, in the Supremacy Clause, that when state and federal law are incompatible, federal law

24396 F. Supp. 2d 383 (S.D.N.Y. 2005), aff'd sub nom. Clearing House Ass'n v. Cuomo, _ F. 3d _, 2007 WL 4233358 (2d Cir. Dec. 4, 2007).

${ }^{25} 12$ C.F.R. 7.4000(a)(3); see also 12 C.F.R. 7.4000(b)(2) (providing that the National Bank Act's "court of justice" exception "pertains to the powers inherent in the judiciary and does not grant state or other governmental authorities any right to inspect, superintend, direct, regulate or compel compliance by a national bank with respect to any law, regarding the content or conduct of activities authorized for national banks under Federal law.”).

${ }^{26}$ OCC v. Spitzer, 396 F. Supp. 2d at 385. For summaries of some other recent episodes in agency preemption, see Myron Levin \& Alan C. Miller, "Industries Get Quiet Protection From Lawsuits,” L.A. Times, Feb. 19, 2006, at A1; Caroline E. Mayer, "Rules Would Limit Lawsuits: U.S. Agencies Seek To Preempt States,” Wash. Post, Feb. 16, 2006, at D01.

${ }^{27}$ See Clearing House Ass'n v. Cuomo, _ F. 3d _, 2007 WL 4233358 (2d Cir. Dec. 4, 2007).

${ }^{28}$ The doctrine is described in greater detail in Chapter Six of this volume, by Professor Schroeder. 
trumps. ${ }^{29}$ Although the doctrine is not always consistently applied, its basic contours are reasonably clear. Preemption may be either express or implied. The former is straightforward: "It is well established that within constitutional limits Congress may pre-empt state authority by so stating in express terms." ${ }^{30}$ The latter is more varied, and may be subdivided into field and conflict preemption: "[A] federal statute implicitly overrides state law either when the scope of a statute indicates that Congress intended federal law to occupy a field exclusively, ... or when state law is in actual conflict with federal law."31 The category of implied conflict preemption may be divided one step further, into cases "where it is 'impossible for a private party to comply with both state and federal requirements"” and cases "where state law 'stands as an obstacle to the accomplishment and execution of the full purposes and objectives of Congress." ${ }^{32}$ This last category, sometimes called obstacle preemption, is where many agency preemption cases may be found.

As the Supreme Court has repeatedly made clear, preemption is ultimately a matter of congressional intent and purpose. ${ }^{33}$ That is, preemption cases are fundamentally about statutory interpretation. Yet the interpretive methods employed in these cases are often based in constitutional or other substantive norms not contained in the statute itself. Perhaps the most significant is the presumption against preemption. It instructs courts to "start with the assumption that the historic police powers of the States were not to be superseded ... unless that was the clear and manifest purpose of Congress." ${ }^{34}$ Of course, the presumption does not apply to all cases, but only to those where preemption would displace some aspect of "the States' historic police powers." 35 It is inapplicable, therefore, "when the State regulates in an area where there has been a history of significant federal presence."36

${ }^{29}$ See U.S. Const. art. VI, cl. 2 (“This Constitution, and the Laws of the United States which shall be made in Pursuance thereof; and all Treaties made, or which shall be made, under the Authority of the United States, shall be the supreme Law of the Land; and the Judges in every State shall be bound thereby, any Thing in the Constitution or Laws of any State to the Contrary notwithstanding.”).

${ }^{30}$ Pac. Gas \& Elec. Co. v. State Energy Res. Conservation \& Dev. Comm’n, 461 U.S. 190, 203 (1983).

${ }^{31}$ Freightliner Corp. v. Myrick, 514 U.S. 280, 287 (1995).

32 Ibid. (quoting English v. General Elec. Co., 496 U.S. 72, 78-79 (1990), and Hines v. Davidowitz, 312 U.S. 52, 67 (1941)).

${ }^{33}$ See, e.g., Medtronic, Inc. v. Lohr, 518 U.S. 470, 485 (1996) (““[T] ultimate touchstone' in every pre-emption case.”) (quoting Retail Clerks Int’l Ass'n v. Schermerhorn, 375 U.S. 96, 103 (1963)).

${ }^{34}$ Rice v. Santa Fe Elevator Corp., 331 U.S. 218, 230 (1947).

${ }^{35}$ Geier v. Am. Honda Motor Corp., 529 U.S. 861, 894 (2000) (Stevens, J., dissenting).

${ }^{36}$ United States v. Locke, 529 U.S. 89, 108 (2000). In addition, there is no presumption against preemption when a state intrudes on the sovereign prerogatives of the federal government by directly regulating the federal government or its agents. See generally Seth P. Waxman \& Trevor W. Morrison, "What Kind of Immunity? Federal Officers, State Criminal Law, and the Supremacy Clause," Yale Law Journal 112, no. 8 (2003): 2195. 
Quite clearly, the presumption against preemption is "rooted in the concept of federalism" 37 - specifically, the idea that the Constitution contemplates an ongoing role for the states in areas traditionally regulated by them, and that the courts ought to interpret federal laws with a presumption in favor of preserving that role. In that respect, it is similar to certain clear statement rules developed in cases like Gregory v. Ashcroft. In Gregory, the Court considered whether a federal statute banning age discrimination in employment applied to state judges despite a state constitutional requirement that they retire by age 70 . The case came to the Court only a few years after it had decided, in Garcia v. San Antonio Metropolitan Transit Authority, ${ }^{38}$ that any constitutionally-based norm against congressional encroachment on core state governmental functions was not susceptible to direct judicial enforcement. For the Gregory Court, that lack of direct judicial enforcement provided a basis for adopting a federalism-favoring rule of statutory construction: "[I]nasmuch as this Court in Garcia has left primarily to the political process the protection of the States against intrusive exercises of Congress' Commerce Clause powers, we must be absolutely certain that Congress intended such an exercise.”39 To that end, the Court announced that it would not construe federal statutes to "upset the usual constitutional balance of federal and state powers" unless Congress has made "its intention to do so unmistakably clear in the language of the statute."40 Finding no clear statement that the age discrimination statute was intended to apply to core state functions, the Court held it did not apply to state judges.

The larger idea behind clear statement rules of this sort is that federal regulation of areas of core state concern has the potential to significantly change the federal-state balance, even where federal law just creates a regulatory overlay. Concerns driving clear statement rules are at their apex if federal law preempts state regulatory power in an area of traditional state concern or seeks to regulate core state governmental functions themselves. And although it may be within Congress's power to effect such changes, the Court has declared that it will not deem Congress to have done so absent a clear statutory statement to that effect. ${ }^{41}$ Viewed in this light, clear statement rules of this sort share a certain kinship with the presumption against preemption. ${ }^{42}$ Both implement federalism norms by directing courts to interpret statutes so as to favor the preservation of certain state powers, roles, and prerogatives. ${ }^{43}$

${ }^{37}$ Geier, 529 U.S. at 907 (Stevens, J., dissenting)

${ }^{38} 469$ U.S. 528 (1985).

${ }^{39} 501$ U.S. at 464.

${ }^{40}$ Ibid., 460.

${ }^{41}$ See Will v. Michigan Dept. of State Police, 491 U.S. 58, 65 (1989) ('[I]f Congress intends to alter the 'usual constitutional balance between the States and the Federal Government,' it must make its intention to do so 'unmistakably clear in the language of the statute.'” (quoting Atascadero State Hospital v. Scanlon, 473 U.S. 234, 242 (1985)).

${ }^{42}$ See Gregory, 501 U.S. at 461 (referring to the presumption against preemption in the course of defending its clear statement rule).

${ }^{43}$ On the other hand, there are important differences between the presumption against preemption and federalism-protecting clear statement rules. Put simply, the former can be overcome with something less than a clear statutory statement. A true clear statement requirement is really a rule of specific drafting: 
But there is a problem with both the presumption against preemption and federalismenforcing clear statement rules, at least as they are currently formulated. They are all structured around substantive triggers that require courts to identify and attach great consequence to the "historic" functions of the states. Yet in Garcia, the Court rejected a closely related enterprise as "unsound in principle and unworkable in practice." 44 There, the question was whether the Constitution contains a judicially enforceable limit on Congress's authority to regulate states in the performance of traditional state government functions. In rejecting its earlier attempt in National League of Cities v. Usery ${ }^{45}$ to enforce such a limit, the Court concluded, first, that as a practical matter it "ha[d] made little headway in defining the scope" of traditional government functions. ${ }^{46}$ Second, the Court stressed a "more fundamental problem" with the undertaking: even assuming courts could separate the traditional from the modern, there is no reason to think the federal system should favor the former over the latter. ${ }^{47}$ States should be free to innovate within the boundaries of their regulatory authority, and the Constitution should not be construed to hinder such innovation. Thus, the Court abandoned the project of directly enforcing any constitutional limit on the federal government's power to regulate the states, other than the limits entailed in the enumeration of federal power itself.

The presumption against preemption and the Gregory clear statement rule both invite courts to resume essentially the same kind of analysis abandoned in Garcia, though now in service of rebuttable presumptions about statutory meaning. ${ }^{48}$ Yet if the Court was right in Garcia that this sort of analysis is neither feasible nor desirable in the context of direct constitutional enforcement, there is a strong argument that the same should be true for these rules of (constitutionally informed) statutory interpretation. ${ }^{49}$

the requirement can be satisfied only by express language in the text of the statute. See Ernest A. Young, “The Rehnquist Court's Two Federalisms," Texas Law Review 83, no. 1 (2004): 1, 23 n.90. The presumption against preemption, on the other hand, may be better described as an interpretive "standard that simply urges courts to err on the side of state autonomy while still considering all potentially relevant sources of statutory meaning.” Ibid. This is a significant difference. Indeed, “[i]f Gregory's 'plain statement' rule were applied to preemption, . . . entire bodies of preemption doctrine might be called into question." Ibid.

${ }^{44} 469$ U.S. 528, $546-47$ (1985).

45426 U.S. 833 (1976).

${ }^{46}$ Garcia, 469 U.S. at 539.

${ }^{47}$ See ibid., 545-46 ("The essence of our federal system is that within the realm of authority left open to them under the Constitution, the States must be equally free to engage in any activity that their citizens choose for the common weal, no matter how unorthodox or unnecessary anyone else-including the judiciary-deems state involvement to be.”).

${ }^{48}$ Justice Blackmun criticized the Court's decision in Gregory on this very ground. See Gregory, 501 U.S. at 477 (Blackmun, J., dissenting) (criticizing the Court's adoption of a clear statement rule as "directly contraven[ing] our decision in Garcia").

${ }^{49}$ The formal distinction between constitutional and statutory interpretation seems insufficient to support the divergence between Garcia and Gregory. After all, "[a]ny theory of statutory interpretation is at base a theory about constitutional law.” Jerry Mashaw, "As If Republican Interpretation," Yale Law Journal 97, no. 8 (1988): 1685, 1686. 
Moreover, the problems with the presumption against preemption and the Gregory clear statement rule are even more acute when applied to cases involving the potential preemption of the work of state attorneys general. Not only is it impractical to expect courts to be able to determine whether particular issues fall within a zone of "core" or "historic" state concern, but this approach also encourages courts to focus on the subject matter of the laws at issue rather than the institutions involved in the implementation of those laws. This indifference to institutions renders preemption doctrine insensitive to the close connection between the state attorney general and core federalism values like democratic accountability. And by not taking account of that connection, current preemption doctrine does not adequately weigh the federalism-related costs of displacing the work of the state attorney general.

The point here is not that federal law should avoid preempting state attorneys general at all costs. Rather, the point is that the decision whether to preempt should take more direct account of this key state institution. The next Part shows how Congress and federal agencies can do precisely that.

\section{Toward Congressional and Agency Solicitude for State Attorneys General}

It may be an uphill challenge to persuade the courts to become more sensitive to preemption's particular impact on the state attorney general. But Congress and the administrative state need not wait for the courts to take the lead in this area. Instead, they themselves could adopt an approach that takes special account of the state attorney general and that refrains from preempting its work absent a specific legislative choice to do so.

The prescription here contains two straightforward steps. First, when passing a statute that carries the potential of preempting state law to any degree, Congress should devote special consideration to whether any or all of the work of state attorneys general (disaggregating, possibly, the attorney general's investigative and litigating authority) should be preempted, and should include a provision making clear the extent of its intent to preempt. Second, in the absence of such clear statutory language, federal agencies should indulge a strong presumption against preempting state attorneys general by regulation. Both of these suggestions flow from the same underlying view: federal law should preempt the core investigative and enforcement work of state attorneys general only by express statutory language.

The argument in favor of this approach tracks the federalism-related values discussed earlier in this chapter. Most importantly, it protects the values of democratic accountability and self-governance-values which, as discussed in Part I, are core virtues of federalism itself. The connection to those values in this context is plain. When a state attorney general decides to enforce (or investigate compliance with) a particular state law in a particular context, that decision has a double claim to democratic legitimacy: it reflects the democratically accountable state legislature's decision to enact such a law and to make it enforceable by the attorney general, and it also reflects the democratically accountable attorney general's decision to enforce the law when, how, and to the extent he deems appropriate. Federal agencies, in contrast, have a much more attenuated claim 
to democratic legitimacy. They are not directly elected, and as a practical matter they are not subject to particularly close oversight by the President. Thus, to the extent federalism is a means to the ends of democratic accountability and citizen control of government, those ends seem best pursued by shielding state attorneys general from agency preemption.

At the same time, the approach I advocate here leaves Congress entirely free to displace state attorneys general to the extent it deems appropriate. My approach simply encourages Congress to address the state attorney general head-on, and to include express statutory language specifying whether, and to what extent, it intends its law to pre-empt the work of the state attorney general.

This approach ensures that the decision to pre-empt is made via a process structured to take account of the interests of the states. According to the familiar "political safeguards of federalism" thesis, the system of state representation in Congress makes the federal legislative process itself the principal constitutional means of protecting federalism. ${ }^{50}$ But that system is not engaged unless Congress does, in fact, turn its attention to the particular issue at hand. This same thinking underlies the judiciary's use of the federalism-enhancing clear statement rules discussed in Part III. The point of those rules is to help clarify that the democratically accountable federal legislature-not merely a court or administrative agency — did indeed intend to legislate in a way that implicates the federalism norm in question. As the Court has described, "in traditionally sensitive areas, such as legislation affecting the federal balance, the requirement of clear statement assures that the legislature has in fact faced, and intended to bring into issue, the critical matters involved in the judicial decision." ${ }^{51}$ In that sense, clear statement rules express a strong preference between two kinds of potential interpretive errors. By requiring a clear statement before construing a statute to implicate the federalism norm in question, courts express a preference for erring on the side of the states rather than against them. The same is true for the particular approach I am urging here, which would require Congress itself (regardless of how the courts would act) to adopt a practice of specifying the extent to which it intends to preempt the investigative, enforcement, and other core powers of state attorneys general.

Not only does the approach advocated here maximize the democratic accountability of decisions to oust state attorneys general, it also recognizes the enormous potential value of state attorneys general to the enforcement of both state and federal law. Especially given the ever-present pressure on federal agency budgets, the state attorney general can be an invaluable yet cheap (from the perspective of the federal fisc) partner in the law enforcement effort. As discussed above, the exercise of visitorial power by state attorneys general can help federal agencies learn more about the extent to which relevant federal laws and regulations are being followed. Whether or not the agency will then deem formal enforcement proceedings to be in order, the key point is that state attorneys

${ }^{50}$ See generally Herbert Wechsler, "The Political Safeguards of Federalism,” Columbia Law Review 54, no. 4 (1954): 543.

${ }^{51}$ Gregory, 501 U.S. at 464; see EEOC v. Arabian Am. Oil Co., 499 U.S. 244, 262 (1991) (Marshall, J., dissenting) ("Clear-statement rules operate less to reveal actual congressional intent that to shield important values from an insufficiently strong legislative intent to displace them.”). 
general can help the agency make that decision on the basis of better information. That sort of assistance should not be rendered unavailable except by the intentional and express decision of Congress.

Of course, if Congress does include specific language specifying its intent to preempt certain state attorney general activities, the calculus is much different than if the decision to preempt is made by an agency in the face of statutory silence. Instead of an unelected agency displacing the work of an elected state official, the most democratically accountable branch of the federal government will have determined that the costs of allowing state attorneys general to continue to work in the area outweigh the benefits, will have decided therefore to pre-empt that work, and will have memorialized that decision in clear terms. At that point, the federal government will have delivered democratic accountability as best it can. Pre-emption properly follows.

I would note one potential alternative here. Because the decision whether to pre-empt in any particular context requires access to information that Congress did not have at the time it legislated, it may be appropriate for Congress to delegate pre-emption authority to the relevant regulatory agency. It is not my aim here to delve into all the elements of such delegations; Professor Funk addresses them in greater detail in Chapter Ten. Rather, I want only to note that a Congress wanting to delegate pre-emption authority to the agency can still be attentive to the special role of state attorneys general by clearly specifying whether the agency's pre-emption power extends to state attorneys general.

\section{An Objection: The Extraterritoriality Problem}

Having laid out the case for special congressional and agency solicitude for the state attorney general, I now identify and respond to a potential objection to the argument as I have presented it.

One might object to my association of the elected state attorney general with the federalism-related value democratic accountability on the ground that the enforcement actions of state attorneys general are often undemocratic and unaccountable in important ways. The concern here is with extraterritoriality. If, for example, the attorney general in New York successfully sues a manufacturer based in California over defects in its products sold in New York, the effects of a large civil fine or other costly remedy may be borne in part by the workers in the manufacturer's California plant (if it must lay off employees), or even by the average citizens of California (if the layoffs and other changes lead to an economic downturn). ${ }^{52}$ Some scholars maintain that the potential for such extraterritorial effects undermines any attempt to resist preemption on grounds of democracy or self-governance:

If the state juries in, say, Creek County, Oklahoma, routinely impose enormous liability on out-of-state automobile corporations simply to enrich local plaintiffs and

52 See Samuel Issacharoff \& Catherine M. Sharkey, “Backdoor Federalization,” UCLA Law Review 53, no. 6 (2006): 1353, 1386 (noting the "specter of spillover effects, whereby a state uses its liability regime to benefit in-state residents with larger compensation payments, or exports the costs of its regulation to out-of-state manufacturers and product consumers in the rest of the nation.”). 
the local bar, then this is a burden on the self-governing capacity of states where those automobile manufacturers have their primary places of operations. In effect, Oklahoma is regulating and taxing the businesses of Michigan without considering the desires of the persons most affected - those dependent on Michigan's tax base and sources of employment. Why is not such taxation and regulation without representation an attack on "civic republican values"? ${ }^{53}$

Proponents of this view also stress that even Justice Brandeis, the champion of the muchinvoked "laboratory" model of federalism, endorsed state creativity and experimentation only to the extent that it would not harm the rest of the country. ${ }^{54}$ Where the efforts of one state do spill over into another, the argument goes, neither the laboratory model nor the democratic accountability norm applies.

I disagree. Assuming arguendo the existence of extraterritorial effects, it does not follow that, for example, New York and California (in the hypothetical before the block quote above) are identically situated. As discussed in Part I, the structure of our federalist system contemplates overlapping federal and state regulation. The default presumption is in favor of state regulatory authority. In the New York and California hypothetical, preempting the New York lawsuit would mean departing from that default presumption. In contrast, not preempting the lawsuit would not mean the same thing for California. Even if the New York attorney general's suit would have the extraterritorial effects we have assumed, that would not deprive California of its formal regulatory authority. California's ability to achieve all the regulatory outcomes it seeks for its people might be compromised by the economic downturn, but that is not the same as preempting a state's regulatory authority. Federalism and preemption must be principally concerned with the latter, not the former, because otherwise the extraterritoriality concern would swallow our constitutional system's basic presumption in favor of state regulation.

To put the same point slightly differently, every act of state governance inevitably has at least some extraterritorial effects. Even laws, regulations, and initiatives that seem to apply only to entirely in-state entities and populations will inevitably affect that state's comparative position vis-à-vis other states. Yet this observation does not grind federalism to a halt. Instead, we generally accept that the exercise of any one state's regulatory authority can have effects in other states. The mere possibility of such effects should not change the default presumption in favor of state regulation and against preemption. In the context of the hypothetical example raised here, the risk that the New York attorney general's actions might have some adverse consequences for a California entity or person should not, by itself, lead us to abandon our presumption in favor of preserving the attorney general's authority.

53 Roderick M. Hills, "Against Preemption: How Federalism Can Improve the National Legislative Process,” New York University Law Review 82, no. 1 (2006): 1, 5-6. Others have made the same basic point. See, e.g., Issacharoff \& Sharkey, 1387-88.

${ }^{54}$ New State Ice Co. v. Lieberman, 285 U.S. 262, 311 (1932) (Brandeis, J., dissenting) (“It is one of the happy incidents of the federal system that a single courageous state may, if its citizens choose, serve as a laboratory; and try novel social and economic experiments without risk to the rest of the country.") (emphasis added). 
There are limits, of course. First, the Constitution itself imposes limits in the form of the "dormant Commerce Clause." The Supreme Court's doctrine in that area provides that states may not regulate in a manner that unduly discriminates against out-of-state actors $^{55}$ or that controls conduct beyond the state's borders. ${ }^{56}$ Dormant Commerce Clause doctrine, then, addresses the extraterritoriality issue by establishing certain constitutional boundaries within which each state attorney general must operate.

Beyond those constitutional limits, Congress can of course intervene and preempt state attorneys general in a particular field if it concludes that their presence in that field has generated too many extraterritorial costs. Nothing I have said here is intended to deny Congress's authority to intervene in that way. My point, rather, is simply that in light of the state attorney general's democratic pedigree and potential value as an investigator and law-enforcer, Congress should specify when it intends to preempt the work of the state attorney general, or, at the least, when it intends to authorize agencies to do so.

\section{Conclusion}

The state attorney general is a significant institution in state government, combining direct democratic accountability with expansive powers to act in the public interest. Too often, the judicial doctrine of preemption accords no special consideration to the state attorney general. As this chapter has shown, however, Congress and federal agencies can and should overcome that judicial neglect. Put simply, greater solicitude for the state attorney general should become part of the preemption calculus.

${ }^{55}$ See, e.g., Brown-Forman Distillers Corp. v. New York State Liquor Auth., 476 U.S. 573 (1986).

${ }^{56}$ See, e.g., Edgar v. MITE Corp., 457 U.S. 624 (1982). 